\title{
PERFORMANSI PERTUMBUHAN RUMPUT LAUT (Kappaphycus alvarezii) DENGAN MENGGUNAKAN BIBIT HASIL KULTUR DAN NON KULTUR JARINGAN DI BBPBL LAMPUNG
}

\section{PERFORMANCE OF SEAWEED GROWTH (Kappaphycus alvarezii) USING SEAWEED SEEDS THROUGH TISSUE CULTURE AND NON TISSUE CULTURE IN BBPBL LAMPUNG}

\author{
Sri Budiani Samsu Harapan\#, Retno Ayu Mawarti, dan Mugi Mulyono \\ Sekolah Tinggi Perikanan \\ Jl. AUP Pasar Minggu- Jakarta Selatan 12520 \\ E-mail: sri.samsuharapan@kkp.go.id
}

(Diterima: 13 September 2019; Diterima setelah perbaikan: 21 November 2019; Disetujui: 21 November 2019)

\begin{abstract}
ABSTRAK
Rumput laut merupakan salah satu komoditas perikanan penting di Indonesia. Salah satu jenis rumput laut yang dibudidayakan oleh masyarakat adalah Eucheuma cottonii atau yang biasa disebut Kappaphycus alvarezii. Permasalahan yang dihadapi pembudidaya adalah pemilihan bibit rumput laut yang berkualitas. Kajian ini bertujuan untuk mengetahui pertumbuhan dan keuntungan budidaya rumput laut Kappaphycus alvarezii dengan menggunakan bibit hasil kultur jaringan dan non kultur jaringan dengan berat awal tanam sebesar 50 gram. Metode pengumpulan data menggunakan metode observasi, meliputi penimbangan berat dan pengukuran kualitas air (suhu, kecerahan, kedalaman, pH, salinitas, DO). Hasil kajian menunjukkan pertumbuhan bibit rumput laut yang menggunakan bibit hasil kultur jaringan mempunyai pertumbuhan yang lebih baik (berat rata-rata akhir 655,31 gram, pertumbuhan mutlak 605,3 gram dan LPH 6,32\%) untuk bibit kultur jaringan, sedangkan bibit non kultur jaringan (berat rata-rata 385,39 gram, pertumbuhan mutlak 335,39 gram, dan LPH 4,98\%). Berdasarkan perhitungan analisa finansial sederhana,keuntungan yang didapatkan dari penjualan rumput laut yang menggunakan bibit hasil kultur jaringan Rp. 689.200 sedangkan bibit non kultur jaringan sebesaran Rp 221.200 artinya bibit kultur jaringan lebih menguntungkan.
\end{abstract}

KATA KUNCI: Kappaphycus alvarezii; kultur jaringan; pertumbuhan; keuntungan

\begin{abstract}
Seaweed is one of important fisheries commodities in Indonesia. One type of seaweed cultivated by the community is Eucheuma cottonii or commonly called Kappaphycus alvarezii. Good quality seed of Kappaphycus alvarezii seems to be the main problem of it's cultivation. The aims of this study were to find out the growth and profit of different seed of Kappaphycus alvarezii: tissue culture and non tissue culture with weight of 50 gram. Data collection in this study includes growth and water quality parameters (temperature, brightness, depth, $\mathrm{pH}$,salinit and DO). The results showed that the best growth was found in tissue culture seedlings (average weight 655.31 grams, absolute growth 605.3 grams and daily growth rate $6.32 \%$ ) while non-tissue culture seedlings (average weight 385.39 gram, absolute growth 335.39 gran and daily growth rate $4.98 \%$ ). Based on simple financial analysis calculations, the profit gained from the sale of seaweed using seedlings from tissue culture is IDR. 689,200 while non tissue culture seedlings amounting to IDR 221,200 means tissue culture seeds are more profitable.
\end{abstract}

KEYWORDS: Kappaphycus alvarezii; tissue culture; growth; profit

\footnotetext{
\#Korespondensi: Sekolah Tinggi Perikanan
}

E-mail: sri.samsuharapan@kkp.go.id 


\section{PENDAHULUAN}

Salah satu jenis rumput laut yang dibudidayakan oleh masyarakat adalah Eucheuma cottonii atau yang biasa disebut Kappaphycus alvareziïyang termasuk ke dalam jenis (Rhodophyceae) karena karaginan yang dihasilkan merupakan fraksi kappa-karaginan. Jenis ini banyak dibudidayakan karena teknologi produksinya relatif murah dan mudah serta penanganan pasca panen mudah dan sederhana. Selain sebagai bahan baku industri, rumput laut jenis ini juga dapat diolah menjadi makanan yang dapat dikonsumsi secara langsung (Wijayanto et al., 2011). Kappaphycus alvarezii merupakan rumput laut yang menghasilkan karaginan yang bernilai ekonomis tinggi. Karaginan adalah senyawa hidrokoloid dari polisakarida rantai panjang yang diperoleh dari hasil ekstraksi rumput laut dengan menggunakan air panas atau larutan alkali pada temperatur tinggi (Sulistiani \& Yani, 2014). Dalam dunia industri dan perdagangan, karaginan memberikan banyak manfaat diantaranya dalam industri farmasi, makanan dan kosmetik yaitu sebagai stabilisator, bahan pengental, pembentuk gel dan pengemulsi (Parenrengi et al., 2011). Hal ini membuat kubutuhan terhadap karaginan meningkat. Menurut Aslan (2011), peningkatan kebutuhan karaginan rumput laut ditentukan oleh ketersediaan suplai rumput laut, baik secara kuantitas maupun kualitas rumput laut secara kontinyu.

Basis utama untuk menjawab hal tersebut adalah melalui kegiatan budidaya yang berkelanjutan. Keberhasilan budidaya rumput laut tidak lepas dari beberapa faktor seperti pemilihan lokasi, lingkungan, kualitas bibit, metode budidaya yang digunakan, ketersediaan nutrisi dan kepadatan atau bobot awal dalam pemeliharaan. Penggunaan bibit rumput laut yang unggul diharapkan bisa mendapatkan hasil panen yang baik dan produksi tinggi. Namun, lambatnya perkembangan usaha budidaya rumput laut ini disebabkan karena keterbatasan bibit, pertumbuhan Kappaphycus alvarezii tergolong lambat dan rentan terserang penyakit. Selain itu, petani rumput laut juga sering menggunakan bibit yang berulang-ulang dari sumber indukan yang sama, sehingga berpotensi mengalami penurunan kualitas (Sapitri et al., 2016). Hal ini juga dikatakan oleh Santoso \& Nugroho (2008), bahwa teknologi budidaya rumput laut yang sederhana dan murah belum didukung oleh ketersediaan bibit yang berkualitas. Bibit rumput laut masih mengandalkan hasil dari budidaya sehingga akan mengalami penurunan kualitas, baik produktivitasnya maupun ketahanan terhadap penyakit.

Salah satu alternatif yang dapat dilakukan untuk memperoleh bibit rumput laut Kappaphycus alvarezii yang berkesinambungan dan memiliki kualitas baik yaitu dengan teknik kultur jaringan. Rumput laut hasil kultur jaringan memiliki tingkat pertumbuhan lebih tinggi dibandingkan menggunakan bibit rumput laut lokal (Aslan $d k k$., 2016). Kultur jaringan merupakan teknik memperbanyak tanaman dengan cara mengisolasi bagian tanaman seperti daun, mata tunas serta menumbuhkan bagian-bagian tersebut dalam media buatan secara aseptik dalam wadah tertutup sehingga bagian tanaman dapat memperbanyak diri dan beregenerasi menjadi tanaman lengkap. Bibit yang dihasilkan dari kultur jaringan mempunyai keunggulan, antara lain mempunyai sifat yang identik dengan induknya, tidak terlalu membutuhkan tempat yang luas, mampu menghasilkan bibit dengan jumlah besar serta kesehatan dan mutu bibit yang dihasilkan lebih terjamin (Sulistiani \& Yani, 2014).

\section{BAHAN DAN METODE}

\section{Waktu dan Tempat Penelitian}

Penelitian ini dilaksanakan dilaksanakan selama tiga bulan dimulai dari tanggal 04 Maret 2019 sampai dengan 01 Juni 2019 Farm Budidaya Rumput Laut di Balai Besar Perikanan Budidaya Laut (BBPBL) Lampung, Desa Hanura, Kecamatan Padang Cermin, Kabupaten Pesawaran, Provinsi Lampung.

\section{Rancangan Penelitian}

Desain penelitian yaitu melakukan percobaan langsung pada kegiatan pengamatan pertumbuhan rumput laut Kappaphycus alvarezii dengan bibit yang berbeda yaitu bibit hasil kultur jaringan dan non kultur jaringan. Bobot penanaman dengan berat awal masingmasing 50 gram dan dengan 3 kali pengulangan.Bibit rumput laut Kappaphycus alvarezii hasil kultur jaringan berasal dari kebun bibit Balai Besar Perikanan Budidaya Laut (BBPBL) Lampung, sedangkan bibit rumput laut non kultur jaringan berasal dari pembudidaya rumput laut di Serang Banten.

\section{Prosedur Penelitian}

Bibit rumput laut Kappaphycus alvarezii hasil kultur jaringan dan non kultur jaringan dipelihara selama 42 hari dengan berat awal 50 gram dan jarak tanam 20 $\mathrm{cm}$ menggunakan metode budidaya long line berbingkai.Menggunakan 3 tali jalur untuk masingmasing jenis bibit. Tali jalur yang digunakan memiliki panjang $25 \mathrm{~m}$. Dalam satu tali jalur terdapat 120 titik, sehingga berat total untuk 1 tali jalur adalah $6 \mathrm{~kg}$.

Bibit rumput laut kultur jaringan yang digunakan berumur 25 hari, sedangkan bibit non kultur jaringan berumur 28 hari. Bibit rumput laut yang digunakan memiliki krieria bercabang banyak, thallus kuat, warna spesifik, tidak terkelupas, bebas dari kotoran dan 
penyakit.

Pengikatan bibit rumput laut menggunakan ikatan simpul pita kemudian ditanam pada konstruksi long line berbingkai. Menggunakan 3 tali jalur untuk masing-masing jenis bibit. Tali jalur yang digunakan memiliki panjang $25 \mathrm{~m}$. Dalam satu tali jalur terdapat 120 titik, sehingga berat total untuk 1 tali jalur adalah $6 \mathrm{~kg}$.

Selama pemeliharaan dilakukan pengontrolan setiap hari dengan membersihkan organisme dan kotoran yang menempel dengan cara menggoyanggoyangkan tali jalur. Selain itu dilakukan pembuatan arus buatan dengan menggunakan perahu mengelilingi lokasi budidaya rumput laut.

Sampling pertumbuhan dilakukan setiap satu minggu sekali pada pukul $08.00 \mathrm{WIB}$, sedangkan pengukuran kualitas air dilakukan seminggu sekali pada pukul 08.00 WIB.

\section{Variabel Penelitian}

Parameter penelitian yang diamati dan diukur dalam penelitian ini adalah pertumbuhan,kualitas air dan keuntungan. Monitoring atau pemantauan lokasi budidaya rumput laut bertujuan untuk mengamati lokasi budidaya terutama rumput laut terhadap halhal yang dapat mengganggu aktivitas dan pertumbuhan rumput laut. Evaluasi pertumbuhan bobot rumput laut bertujuan untuk mengetahui pertumbuhan rumput laut setiap minggu. Pada unit long line diambil sebanyak $10 \%$ atau diambil sebanyak 30 rumpun secara acak dan dilakukan penimbangan berat. Kegiatan ini dilakukan setiap satu minggu sekali selama 6 minggu penelitian.

Tabel 1. Kualitas air selama pemeliharaan

Table 1. Water quality during maintenance
Parameter kualitas perairan Pengukuran parameter kualitas perairan dilakukan secara fisika dan kimia dan dilakukan satu kali selama pengamatan pertumbuhan rumput laut Eucheuma cottonii. Pengukuran secara fisika, meliputi : suhu, kecepatan arus, kedalaman dan kecerahan dilakukan di lokasi budidaya rumput laut Kappaphycus alvarezii. Pengukuran parameter kimia, meliputi : salinitas, oksigen terlarut (DO), dan derajat keasaman $(\mathrm{pH})$.

\section{HASIL DAN BAHASAN}

\section{Kualitas Air}

Pengukuran kualitas air pada budidaya rumput laut Kappaphycus alvarezii di BBPBL Lampung dilakukan seminggu sekali pukul 08.00 WIB.Hasil pengukuran kualitas air selama masa pemeliharaan dapat dilihat pada Tabel 1 .

Kualitas air merupakan salah satu faktor yang memegang peranan penting terhadap keberhasilan budidaya. Nilai kedalaman selama pemeliharaan adalah 10,4 - 13,9 m. Nilai rata-rata kecerahan selama pemeliharaan yaitu $5,0-7,5 \mathrm{~m}$. Nilai suhu selama pemeliharaan adalah 29,7 - 31 p C. Nilai rata-rata kecepatan arus slama pemeliharaan adalah $30 \mathrm{~cm} /$ detik. Nilai pH selama pemeliharaan $7,8-8,2$. Nilai salinitas selama pemeliharaan adalah 31 - $32 \mathrm{~g} / \mathrm{l}$. Nilai DO selama pemeliharaan adalah 5,05 - 5,97 mg/l. Secara umum, kualitas air yang diukur selama pemeliharaan masih dalam kisaran optimal bagi budidaya rumput laut Kappaphycus alvarezii.

\begin{tabular}{lcccc}
\hline \multicolumn{1}{c}{ Parameter } & Satuan & Nilai & Baku Mutu & Referensi \\
\hline $\mathrm{pH}$ & & $7,8-8,2$ & $7,3-8,2$ & Soejatmiko \& Wisman, 2003 \\
Suhu & ${ }^{\circ} \mathrm{C}$ & $29,7-31$ & $25-30$ & Setiysnto et al., 2008 \\
Salinitas & $\mathrm{g} / 1$ & $30-32$ & $28-35$ & Pongarrang et al., 2013 \\
DO & $\mathrm{mg} / 1$ & $5,05-5,97$ & $5,1-6,6$ & Aslan, 2011 \\
Kecerahan & $\mathrm{m}$ & $5,0-7,5$ & $6-8$ & Mubarak et al., 1990 \\
Kedalaman & $\mathrm{m}$ & $10,4-13,9$ & $2-15$ & Ditjenkanbud, 2005 \\
Arus & $\mathrm{cm} / \mathrm{dtk}$ & $25-30$ & $20-40$ & Ditjenkanbud, 2009 \\
\hline
\end{tabular}




\section{Pertumbuhan Rumput Laut}

Hasil pengamatan pertumbuhan berat rata-rata dapat dilihat pada Gambar1.

Terjadi perbedaan berat rata-rata antara bibit kultur jaringan dan bibit non kultur jaringan. Pada minggu pertama berat rata-rata bibit kultur jaringan adalah 91,64 gram sedangkan bibit non kultur jaringan 74,36 gram. Pada minggu kedua, berat rata-rata bibit kultur jaringan adalah 144,4 gram sedangkan bibit non kultur jaringan 102,2 gram. Pada minggu ketiga, berat ratarata bibit kultur jaringan adalah 209 gram sedangkan bibit non kultur jaringan 140,1 gram. Pada minggu keempat, berat rata-rata bibit kultur jaringan adalah 293,9 gram sedangkan bibit non kultur jaringan 203,2 gram. Pada minggu kelima, berat rata-rata bibit kultur jaringan adalah 484,9 gram sedangkan bibit non kultur jaringan 301 gram. Pada minggu keenam, berat ratarata bibit kultur jaringan adalah 655,3 gram sedangkan bibit non kultur jaringan 385,3 gram. Maka, selisih berat rata-rata antara bibit kultur jaringan dan bibit non kultur jaringan pada sampling keenam adalah 270 gram. Apabila dibandingkan dengan penelitian Wijayanto dkk., (2011), berat rata-rata bibit kultur jaringan lebih tinggi sedangkan bibit non kultur jaringan lebih rendah.

Pertumbuhan mutlak adalah pertumbuhan berat (gram) rumput laut dengan menghitung selisih antara berat akhir dengan berat awal. Nilai pertumbuhan mutlak rumput laut per minggunya dapat dilihat pada Gambar 2.

Pada grafik diatas, menunjukkan bahwa pertumbuhan berat rumput laut Kappaphycus alvareii selama penanaman 42 hari meningkat kecuali pada minggu keenam, baik untuk yang kultur jaringan maupun yang non kultur jaringan. Pada minggu pertama penambahan berat rata-rata rumput laut kultur jaringan sebesar 41,64 gram sedangkan yang non kultur jaringan 24,36 gram. Pada minggu kedua, penambahan berat rata-rata rumput laut kultur jaringan sebesar 52,78 gram sedangkan yang non kultur jaringan 27,86 gram. Pada minggu ketiga, penambahan berat rata-rata rumput laut kultur jaringan sebesar 64,58 gram sedangkan yang non kultur jaringan 37,89 gram. Pada minggu keempat, penambahan berat rata-rata rumput laut kultur jaringan sebesar 84,94 gram sedangkan yang non kultur jaringan 63,14 gram. Pada minggu kelima, penambahan berat rata-rata rumput laut kultur jaringan sebesar 191,03 gram sedangkan yang non kultur jaringan 97,78 gram. Pada minggu keenam, penambahan berat rata-rata rumput laut kultur jaringan sebesar 170,33 gram sedangkan yang non kultur jaringan 84,36 gram. Pada minggu keenam penambahan berat rata-rata rumput laut mengalami penurunan dibandingkan minggu-minggu sebelumnya baik untuk rumput laut yang kultur jaringan maupun yang non kultur jaringan.

Laju pertumbuhan harian merupakan perbandingan berat awal rumput laut dengan berat akhir rumput laut setiap harinya. Laju pertumbuhan rumput laut dipengaruhi oleh dua faktor yaitu faktor eksternal dan faktor internal. Faktor internal antara lain jenis, bagian thallus dan umur. Sedangkan faktor eksternal antara lain keadaan lingkungan fisik dan kimiawi perairan. Selain faktor-faktor tersebut, ada faktor lain yaitu faktor pengelolaan yang dilakukan oleh manusia. Faktor pengelolaan oleh manusia dalam kegiatan rumput laut kadang merupakan faktor utama yang harus diperhatikan seperti jarak tanam bibit. Laju pertumbuhan harian rumput laut dapat dilihat pada Gambar 3.

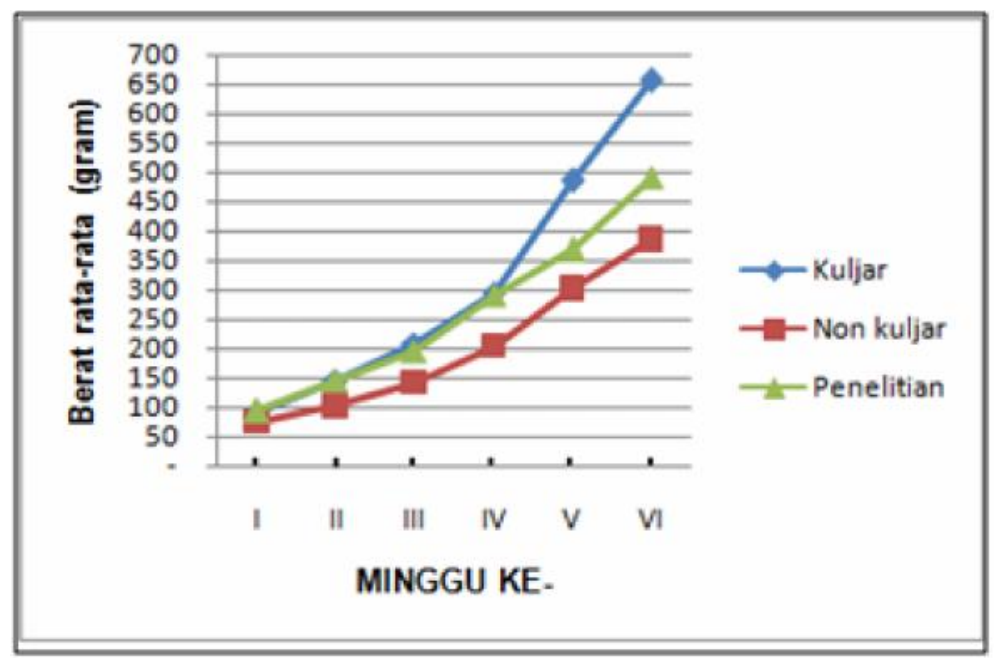

Gambar 1. Hasil sampling (Minggu Ke- ) berat rata-rata rumput laut.

Figure 1. Sampling results (Week to) average weight of seaweed. 


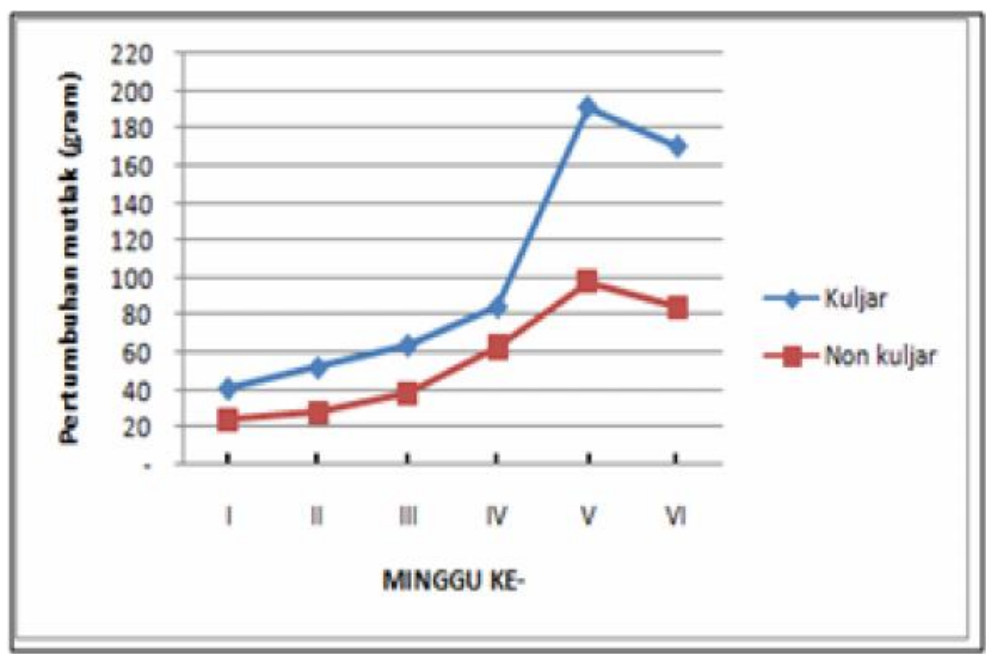

Gambar 2. Pertumbuhan mutlak rumput laut.

Figure 2. Absolute growth of seaweed.

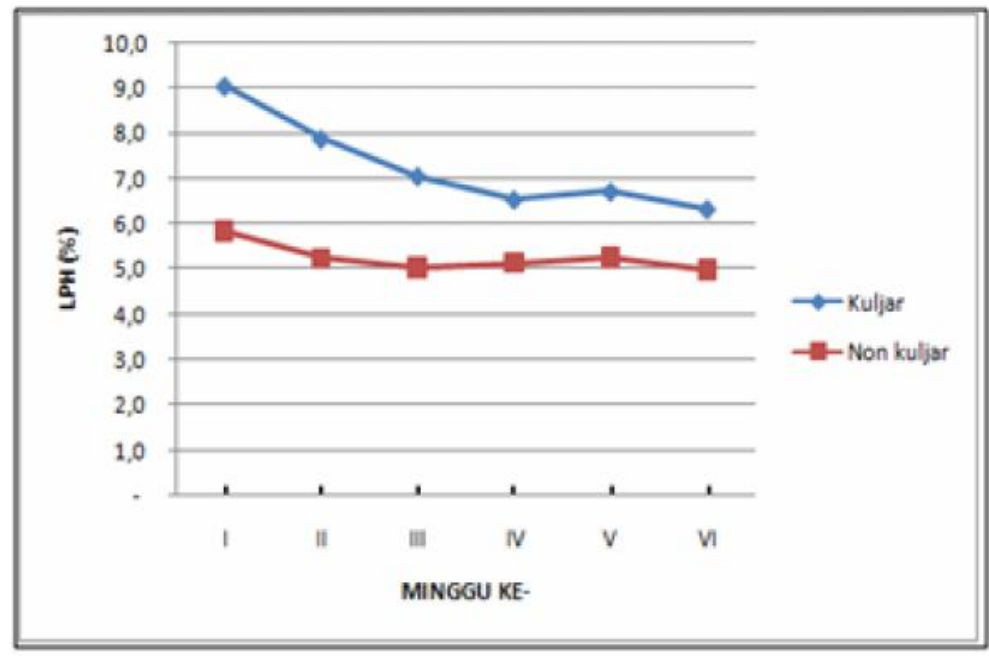

Gambar 3. Laju pertumbuhan harian.

Figure 3. Daily growth rate.

Pada minggu pertama, LPH rumput laut kultur jaringan adalah 9,04\% sedangkan yang non kultur jaringan 5,83\%. Pada minggu kedua, LPH rumput laut kultur jaringan adalah $7,87 \%$ sedangkan yang non kultur jaringan 5,24\%. Pada minggu ketiga, LPH rumput laut kultur jaringan adalah $7,05 \%$ sedangkan yang non kultur jaringan 5,03\%. Pada minggu keempat, LPH rumput laut kultur jaringan adalah 6,53\% sedangkan yang non kultur jaringan 5,14\%. Pada minggu kelima, LPH rumput laut kultur jaringan adalah 6,71\% sedangkan yang non kultur jaringan 5,26\%. Pada minggu keenam, LPH rumput laut kultur jaringan adalah $6,32 \%$ sedangkan yang non kultur jaringan 4,98\%.

Jadi laju pertumbuhan harian rumput laut yang menggunakan bibit kultur jaringan selama pemeliharaan sebesar 6,32\% dan yang menggunakan bibit non kultur jaringan sebesar 4,98\%. Laju pertumbuhan ini dikatakan baik karena melebihi $3 \%$, hal ini sesuai pendapat Supratno (2007), kegiatan budidaya rumput laut dikategorikan baik jika laju pertumbuhan hariannya rata-rata minimal 3\% . Hal ini juga didukung pernyataan Iksan (2005) dan Sutrian (2004), laju pertumbuhan yang dianggap cukup menguntungkan adalah 3\% per hari.

Lebih tingginya pertumbuhan rumput laut dengan bibit hasil kultur jaringan diduga karena memiliki materi genetik yang baik dibandingkan dengan bibit non kultur jaringan, hal ini sesuai dengan pendapat Pong-Masak dan Simatupang (2017) bahwa gen adalah faktor pembawa sifat penurunan yang terdapat dalam seluruh makhluk hidup. Bibit dengan turunan gen yang baik memiliki kemampuan adaptasi yang lebih baik terhadap perubahan lingkungan, lebih tahan penyakit serta kemampuan dalam menyerap nutrien dari 
lingkungannya juga lebih baik. Selain itu, Fadilah et al. (2015) mengatakan bahwa rumput laut hasil kultur jaringan memiliki pertumbuhan yang lebih tinggi, juga memiliki konsentrasi hormon pertumbuhan tanaman khususnya kinetin lebih besar dibanding rumput laut non kultur jaringan.

\section{Keuntungan}

Hasil penghitungan keuntungan yang didapatkan dari penjualan rumput laut yang menggunakan bibit hasil kultur jaringan lebih besar yaitu Rp. 689.200,sedangkan keuntungan penjualan rumput laut yang menggunakan bibit non kultur jaringan sebesar Rp. 221.200,- (Tabel 2.)

Tabel 2. Analisa laba/rugi bibit kultur jaringan dan non kultur jaringan

Table 2. Analysis of profit / loss of tissue culture and non-tissue culture seedlings

\begin{tabular}{lccc}
\hline \multicolumn{1}{c}{ Jenis Bibit } & Modal (Rp) & Pendapatan (Rp) & Keuntungan (Rp) \\
\hline Kultur Jaringan & 126.800 & 816.000 & 689.200 \\
Non Kultur Jaringan & 108.800 & 330.000 & 221.200 \\
\hline
\end{tabular}

\section{KESIMPULAN}

Pertumbuhan dan keuntungan rumput laut Kappaphycus alvarezii yang menggunakan bibit hasil kultur jaringan lebih tinggi dibandingkan yang menggunakan bibit non kultur jaringan.

\section{UCAPAN TERIMA KASIH}

Ucapan terimakasih disampaikan kepada Balai Besar Perikanan Budidaya Laut (BBPBL) Lampung, atas fasilitas dan dukungannya pada penelitian ini.

\section{DAFTAR PUSTAKA}

Aslan, La Ode M. (2011). Budidaya Rumput Laut. Penerbit Kanisius, Yogyakarta.

Aslan, La Ode M., Ruslaini., Iba, W., Armin., \& Sitti. (2016). Cara Budidaya Rumput Laut Kappaphycus alvarezii Menggunakan Bibit Hasil Kultur Jaringan. Panduan Praktis Budidaya Rumput Laut No.1. Universitas Halu Oleo. Kendari.

Direktorat Jenderal Perikanan dan Budidaya. (2005). Profil Rumput Laut Indonesia. Direktorat Jenderal Perikanan Budidaya Departemen Kelautan dan Perikanan. Jakarta.

Direktorat Jenderal Perikanan dan Budidaya. (2009). Profil Rumput Laut Indonesia. Direktorat Jenderal Perikanan Budidaya Departemen Kelautan dan Perikanan. Jakarta.

Fadilah, S., Alimuddin., Pong-Masak, P.R., Santoso, J., \& Parenrengi, A. (2016). Growth, Morphology and Growth-Related Hormone Level in Kappaphycus alvarezii Produced by Mass Selection in Gorontalo Waters, Indonesia. Hayati Journal of Bioscience. 23: 29-34.

Iksan, K. H. (2005). Kajian Pertumbuhan, Produksi Rumput Laut Eucheuma cottonii dan Kandungan
Karaginan pada Berbagai Bobot Bibit dan Asal ThalIus di Perairan Desa Guraping Oba Maluku Utara. Tesis. Fakultas Perikanan dan Ilmu Kelautan. Institut Pertanian Bogor.

Kementrian Kelautan dan Perikanan (KKP). (2014). Profile of Business and Investment Opportunites on Seaweed in Indonesia. Jakarta.

Kordi, M. G. H. (2011). Kiat Sukses Budidaya Rumput Laut di Laut dan Tambak. Andi Offset. Yogyakarta. 134 Hal.

Mubarak, H., Ilyas, S., Ismail, W., Wahyuni, I.S., Hartati, S.H., Pratiwi, E., Jangkaru, Z., \& Arifuddin, R. (1990). Petunjuk Teknis Budidaya Rumput Laut. Pusat Penelitian dan Pengembangan Perikanan. PHP/KAN/PT/13/1990. Jakarta. 93 Hal.

Parenrengi, A., Rachmansyah \& Suryati, E. (2011). Budidaya Rumput Laut Penghasil Karaginan (Karaginofit). Balai Riset Perikanan Budidaya Air Payau. Badan Penelitian dan Pengembangan Kelautan dan Perikanan. Jakarta. ISBN: 978-9793692-21-0. $54 \mathrm{hlm}$.

Pongarrang, D., Rahman, A., \& Iba, W. (2013). Pengaruh Jarak Tanam dan Bobot Bibit terhadap Pertumbuhan Rumput Laut Kappaphycus alvarezii Menggunakan Metode Vertikultur. Jurnal Mina Laut Indonesia. 3(12): 94-112.

Pong-Masak, P.R \& Simatupang N.F. (2017). Penerapan Seleksi Varietas Untuk Produksi Bibit Unggul Rumput Laut Eucheuma denticulatum di Perairan Kupang, Nusa Tenggara Timur. Prosiding Seminar Nasional Tahunan XIV Hasil Penelitian Perikanan dan Kelautan. UGM Yogyakarta. Hal: 141-149.

Runtuboy, N., \& Sahrun. (2001). Rekayasa Teknologi Budidaya Rumput Laut (Kappaphycus alvarezii). Laporan Tahunan Balai Budidaya Laut Tahun Anggaran 2000. Balai Budidaya Laut. 112-117 p. 
Santoso., Limin., \& Nugraha Y.T. (2008). Pengendalian Penyakit Ice - Ice Untuk Meningkatkan Produksi Rumput Laut Indonesia. Jurnal Saintek Perikanan. 3(2). Hal $37-43$.

Sapitri, A.R., Cokrowati, N., \& Rusman. (2016). Pertumbuhan Rumput Laut Kappaphycus alvarezii Hasil Kultur Jaringan Pada Jarak Tanam Berbeda. Jurnal Depik. 5(1): 12-18.

Setiyanto, D., Efendi, I., \& Antara, K.J. (2008). Pertumbuhan Kappaphycusalvareziivar Maumare, var Sacol dan Eucheuma cottonii di perairan Musi Buleleng. Jurnal IImu Kelautan. 13 (3):171-176.

Soejatmiko, W., \& Wisman I.A. (2003). Teknik Budidaya Rumput Laut dengan Metode Tali Panjang. www.iptek.net.id/ttg/artlkp/artikel1 8.htm. Diakses pada Tanggal 20 Juni 2019.
Sulistiani, E., \& Yani, S.A. (2014). Kultur Jaringan Rumput Laut Kotoni (Kappaphycus alvarezii). Seamo Biotrop. Bogor.

Supratno, T. K. P. (2007). Prosiding Pemasyarakatan Teknologi Perikanan. Balai Besar Pengembangan Budidaya Air Payau. Jepara.

Sutrian, Y. (2004). Pengantar Anatomi TumbuhanTumbuhan Tentang Jaringan Sel dan Jaringan. PT. Rineka Cipta. Jakarta.

Wijayanto, Tri., Hendri, M., \& Aryawati, R. (2011). Studi Pertumbuhan Laut Eucheuma cottonii dengan Berbagai Metode Penanaman yang Berbeda di Perairan Kalianda Lampung Selatan. Universitas Sriwijaya, Indralaya Indonesia. Maspari Journal03 (51-57). 